\title{
Kinetics and Equilibrium Studies for Removal of Reactive Red 198 From Aqueous Solutions Using Zero Valent Iron powder
}

\author{
Sudabeh Pourfadakari ${ }^{1,2}$; Amir Hossein Mahvi ${ }^{3,4,5, *}$ \\ ${ }_{1}^{1}$ Department of Environmental Health Engineering, School of Health, Shiraz University of Medical Sciences, Shiraz, IR Iran \\ ${ }^{2}$ Student Research Committee, Shiraz University of Medical Sciences, Shiraz, IR Iran \\ 3 Department of Environmental Health Engineering, School of Public Health, Tehran University of Medical Sciences, Tehran, IR Iran \\ ${ }_{4}^{4}$ National Institute of Health Research, Tehran University of Medical Sciences, Tehran, IR Iran \\ ${ }_{5}^{5}$ Center for Solid Waste Research, Institute for Environmental Research, Tehran University of Medical Sciences, Tehran, IR Iran \\ *Corresponding author: Amir Hossein Mahvi, Department of Environmental Health Engineering, School of Public Health, Tehran University of Medical Sciences, Tehran, IR Iran. Tel: \\ +98-2188954914, Fax: +98-2188950188, E-mail: ahmahvi@yahoo.com
}

Received: September 16, 2013; Revised: October 27, 2013; Accepted: October 27, 2013

\begin{abstract}
Background: The complex aromatic structures of dyes make them more stable and more difficult to remove from aqueous solutions. Thus, it is essential to remove dyes from wastewater before discharging them into environment.

Objectives: This study aimed to investigate the efficiency of zero valent iron powder (ZVI) in removing reactive red 198 (RR-198) from aqueous solutions and analyze adsorption isotherms and kinetics.

Materials and Methods: In this laboratory study, all experiments were performed in batch systems. This study investigated the effect of various factors, such as initial dye concentration, contact time, iron powder dose, and pH, on dye removal. The adsorption adsorption parameters were determined based on Langmuir, Freundlich and Temkin isotherms, while the kinetic models were used to establish the adsorption mechanism.

Results: The results of this research showed $\mathrm{pH}=3$ and contact time $=120$ minutes, increasing the $\mathrm{ZVI}$ dose from 200 to $5000 \mathrm{mg} / \mathrm{L}$ in 100 $\mathrm{mg} / \mathrm{L}$ dye concentration, increased the adsorption efficiency from $36.78 \%$ to $97.57 \%$. RR-198 removal followed the Freundlich isotherm $\left(\mathrm{R}^{2}=\right.$ 0.996 at $25^{\circ} \mathrm{C}$ ) and the pseudo-second-order kinetic model.

Conclusions: Considering the simplicity and efficiency of zero valent iron powder, this method is recommended for removing azo dyes from aqueous environments.
\end{abstract}

Keywords:Adsorption; Equilibrium; reactive red 198

\section{Background}

Synthetic dyes are widely used by various industries, such as textile, tanning, leather, paper, and pulp mills. Textile industry wastewater is the main source of environmental pollution as dyes are resistant to degradation $(1,2)$. Synthetic dyes are generally classified into reactive, acidic, basic, vat, dispersing, direct, sulfur, etc. among which, reactive and acidic dyes are the most widely used $(2,3)$. More than 700000 tons of dye are produced around the world annually, and it is estimated that $2 \%$ of dyes produced may enter into wastewater $(4,5)$. In textile industries, almost $1 \%$ to $20 \%$ of dyes enter wastewater due to the impaired performance of the dyeing unit (6). Synthetic colors usually have aromatic molecular structures similar to those of benzene, naphthalene, anthracene, toluene and xylene, making them stable in the environment and more resistant to decomposition. Most of these dyes are toxic and might even be carcinogenic (5). Furthermore, reactive dyes are widely used in the textile industry due to their ease of use, which simply contaminates water because they are highly soluble. The existence of a reactive dye in aquatic environments can decrease self-purification capacity as well as the photosynthesis processes. For this reason, dyes are needed to be removed from wastewater before being discharged into the environment. Reactive red 198 (RR-198) is among this group of dyes and it was selected as the model reactive dye for this study (7). Contaminated waste water is normally treated using biological, physical, and chemical methods. Because of their complex structures they are hard to degrade utilizing biological methods and are generally treated by physical and chemical methods (8) including oxidation, coagulation and flocculation, adsorption, electrochemical, electrolysis, precipitation and membrane filtration. Most of these methods are expensive while not effective for a wide range of dyes (9-11). Of late, zero valent iron (ZVI) has been used to remove contaminants from water and wastewater due to its low toxicity, low cost, and high efficiency (2). Zero-iron powder is a strong reducing agent. Iron particles can easily be recycled through a magnet. It can be used for a wide 
range of contaminants, including chlorinated organic compounds such as phenol, aromatic nitro compounds, nitrate, herbicides and heavy metal ions. Dyes are also oxidized by zero valent iron (12). Metallic iron reacts in aquatic environments as follows (Equations 1, 2,3) $(2,13)$ :

Equation 1. $\quad \mathrm{FeO} \rightarrow F^{+2}+2 e^{-}$

Equation 2. $\mathrm{FeO}+\mathrm{H} 2 \mathrm{O} \rightarrow \mathrm{F} e^{+2}+H_{2}+2 \mathrm{OH}^{-}$

Equation 3. $2 \mathrm{FeO}+\mathrm{O}_{2}+2 \mathrm{H}_{2} \mathrm{O} \rightarrow 2 \mathrm{Fe}^{+2}+4 \mathrm{OH}^{-}$

In the above mentioned reactions, two free electrons are produced and used as the recovery agent. Moreover, divalent iron in aquatic environments is oxidized as follows and creates sediments. One electron is also released during this reaction (Equation 4).

Equation 4. $F e^{+2}+H 2 \mathrm{O} \rightarrow \mathrm{Fe}^{+3}+e^{-}$

Three electrons are released during oxidization of zero valent to trivalent iron, replacing the ions of organic compounds and leading to their decomposition.

\section{Objectives}

Considering the advantages mentioned for ZVI, the present study aims: 1) to investigate the efficiency of zero valent iron powder in removing reactive red 198 (RR-198) from aqueous solutions, 2) to investigate the influence of other variables, including contact time, $\mathrm{pH}$ of solution, ZVI dose and initial dye concentration and 3) to analyze adsorption of isotherms and kinetics.

\section{Materials and Methods}

Iron powder exceeding 98\% purity and effective particle size of $150 \mu$ was purchased from Merck Company, Germany and used without additional treatment. In addition, reactive red 198 with 95\% purity was purchased from Alvan Sabet Company, Hamedan, Iran and employed without additional treatment. The features of the utilized dye are presented in Table 1. Other chemicals with laboratory purity, used in the study, were also prepared by Merck Company, Germany.

\subsection{Methods}

The present applied study was conducted to assess adsorption of RR-198 by zero valent iron particles in batch systems. To perform the experiments $250 \mathrm{~mL}$ laboratory jars were used. Besides, $\mathrm{HCl}$ and $\mathrm{NaOH} 1 \mathrm{~N}$ were used in order to adjust the pH level. The effect of different parameters, including reaction time (5-150 minutes), initial dye concentration $(20,50,100$ and $200 \mathrm{mg} / \mathrm{L}), \mathrm{pH}(3-10)$ and (ZVI) powder (200, 500, 1000, 2500 and $5000 \mathrm{mg} / \mathrm{L}$ ) on the dye removal process were assessed. Mixing was performed by a shaker (rotator R430) with $150 \mathrm{rpm}$. At the end of the equilibrium time, in order to separate the zero valent iron powder from the dye solution, the samples were centrifuged at $4000 \mathrm{rpm}$ for 10 minutes and passed through $0.2 \mu$ filter paper $(12,14,15)$. Finally, the remaining dye concentration in the solution was analyzed by UV/Vis spectrophotometer (Hatch-DR5000, Germany)

\begin{tabular}{l} 
Table 1. Features of Dye Used in the Study \\
\hline Parameter \\
\hline Type color \\
Symbol \\
Chemical formula \\
Molecular weight, g/mol \\
Wave length of maximum absorption, $\mathbf{n m}$ \\
Chemical structure of color
\end{tabular}


at a wave length of $518 \mathrm{~nm}$ according to the standard methods and efficiency was measured (16). In this study, using each factor method independently, each parameter was separately optimized and sample size was determined. The sample size of this study was 101. The amount of dye adsorbed by the adsorbent $(\mathrm{mg} / \mathrm{g})$ and adsorption efficiency (\%) were obtained using Equations 6 and 7 (17).

Equation 5. $\quad \mathrm{qe}=\frac{\left(C_{o}-C_{t}\right) V}{M}$

Equation 6. $\operatorname{Re}(\%)=\frac{\left(C_{0}-C_{t}\right)}{C_{0}} X 100$

Where $\mathrm{q}_{\mathrm{e}}$ is the amount of adsorbed dye $(\mathrm{mg} / \mathrm{g}), \mathrm{C}_{0}$ is the initial dye concentration in the solution $(\mathrm{mg} / \mathrm{L}), \mathrm{C}_{t}$ is the remaining dye concentration in the solution $(\mathrm{mg} / \mathrm{L}), \mathrm{V}$ is the volume ( $\mathrm{L}$ ) and $\mathrm{M}$ is the adsorption dose $(\mathrm{g})$.

\subsection{Adsorption Isotherm and Kinetics}

In this study, the equilibrium of adsorption data was investigated using Langmuir, Ferundlich and Temkin isotherm models. The experiments were performed by changing the initial dye concentration from 20 to 200 $\mathrm{mg} / \mathrm{L}$ with a zero valent iron powder dose of $5000 \mathrm{mg} / \mathrm{L}$, at a temperature of $25^{\circ} \mathrm{C}$ and the equilibrium time of 120 minutes. The Langmuir isotherm is the most applicable adsorption isotherm. Saturated monolayer adsorption is presented by Equation 8 (18):

Equation 7. $\quad q_{e}=\frac{Q_{m} K_{L} C_{e}}{1+K_{L} C_{e}}$

The linear form of the Langmuir equation is presented as follows (Equation 9):

Equation 8. $\frac{1}{q_{e}}=\frac{1}{Q_{m}}+\left(\frac{1}{K_{L} Q_{m}}\right) \frac{1}{C_{e}}$

Where $\mathrm{q}_{\mathrm{e}}$ is the quantity of adsorbed dye $(\mathrm{mg} / \mathrm{g}), \mathrm{C}_{\mathrm{e}}$ is the equilibrium concentration of the dye in the solution ( $\mathrm{mg} / \mathrm{g}), \mathrm{K}_{\mathrm{L}}$ is the Langmuir constant $(\mathrm{L} / \mathrm{mg})$ and $\mathrm{Q}_{\mathrm{m}}$ is the theoretical monolayer saturation capacity $(\mathrm{mg} / \mathrm{g})$. The Freundlich isotherm describes equilibrium on heterogeneous surfaces and hence does not assume monolayer capacity. The Ferundlich isotherm equation is as follows:

Equation 9. $\quad q_{e}=K_{f} C_{e}^{\frac{1}{n}}$

The linear form of the Ferundlich equation is also presented as follows (Equation 11):
Equation 10. $\log q_{e}=\log K_{f}+\left(\frac{1}{n}\right) \log C_{e}$

Where, $\mathrm{q}_{\mathrm{e}}$ is the quantity of adsorbed dye per unit mass of adsorbent (mg/g), $\mathrm{C}_{\mathrm{e}}$ is RR-198 concentration in the solution at equilibrium $(\mathrm{mg} / \mathrm{L})$, and $\mathrm{K}_{\mathrm{f}}$ and $\mathrm{n}$ are the Ferunlich constants which are appropriate to the adsorption capacity and the adsorbent adsorption intensity, respectively. The values of $\mathrm{K}_{\mathrm{f}}$ and $\mathrm{n}$ can be obtained from the intercept and slope of the linear plot of $\log \mathrm{q}_{\mathrm{e}} \mathrm{vs} . \log \mathrm{C}_{\mathrm{e}}$. The Temkin isotherm equation is presented as follows (Equation 12) (19):

Equation 11. $q_{e}=B_{1} L_{n}\left(K_{t} C_{e}\right)$

The linear form of the Temkin equation is presented as follows (Equation 13):

Equation 12. $q_{e}=B_{1} \operatorname{In} K_{T}+B_{1} \operatorname{In} C_{e}$

In this study, $\mathrm{K}_{\mathrm{T}}$ and $\mathrm{B}_{1}=\mathrm{RT} / \mathrm{b}$ are constant, $\mathrm{R}$ is the gas constant ( $8.314 \mathrm{j} / \mathrm{mol} \mathrm{k}), \mathrm{T}(\mathrm{k})$ is the absolute temperature, $\mathrm{K}_{\mathrm{T}}$ is the equilibrium bond constant $(\mathrm{L} / \mathrm{mg}$ ) related to the maximum bond energy and $\mathrm{B}_{1}$ is related to adsorption heat. Moreover, in order to assess the adsorption process of RR-198 on zero valent iron powder, pseudo-first-order, pseudo-second-order and intra-particle diffusion kinetic models were investigated. These models describe the adsorption of dye of RR198, on the ZVI. The kinetics equations are shown in Table 2.

\section{Results}

\subsection{Effect of Contact Time}

Dye removal was investigated at the contact time of 5 to 150 minutes, with initial dye concentration of, $100 \mathrm{mg} / \mathrm{L}$, $\mathrm{pH}=3$ and $5000 \mathrm{mg} / \mathrm{L}$ dose of zero valent iron powder. The effect of contact time on the dye removal percentage is shown in Figure 1. The results indicated that as the time increased, dye removal efficiency increased. Adsorption speed was fast and contaminants removal accelerated during the first 60 minutes; thereafter, it followed a constant slope and reached equilibrium after 120 minutes.

\subsection{Effect of $p H$}

In order to assess the effect of $\mathrm{pH}$ on RR-198 removal, the experiments were performed at the $\mathrm{pH}$ ranges of 3 to 10 , initial dye concentration of $100 \mathrm{mg} / \mathrm{L}$, contact time of 5 - 120 minutes and a 5000 A constant slope $\mathrm{mg} / \mathrm{L}$ dose of zero valent iron powder. The results are presented in Figure 2. Figure 2 indicates that as $\mathrm{pH}$ level increased from 3 to 10 , dye removal efficiency reduced from $97.34 \%-84.68 \%$. By decreasing $\mathrm{pH}$ level from 10 to 3, adsorption capacity increased from 16.93 to $19.46 \mathrm{mg} / \mathrm{g}$. 


\begin{tabular}{lcc}
\hline \begin{tabular}{lc} 
Table 2. Kinetic Equations and Linear Forms (20) \\
\hline Kinetics
\end{tabular} & Equation & Linear Form \\
\hline Pseudo-first-order & $\frac{d q_{t}}{d_{t}}=K_{1}\left(q_{e}-q_{t}\right)$ & $\log \left(q_{e}-q_{t}\right)=\log \left(q_{e}\right)-\frac{K_{1}}{2.303} t$ \\
Pseudo-second-order & $\frac{d q_{t}}{d_{t}}=K_{2}\left(q_{e}-q_{t}\right)^{2}$ & $\frac{t}{q_{t}}=\left(\frac{1}{K_{2} q_{e}^{2}}\right)+\left(\frac{1}{q_{e}}\right) t$ \\
Intra-particle diffusion & $q_{t}=K_{\text {dif }} t^{0.5}+C$ \\
\hline
\end{tabular}

Figure 1. Effect of Equilibrium Time on RR-198 Adsorption Process Using ZVI

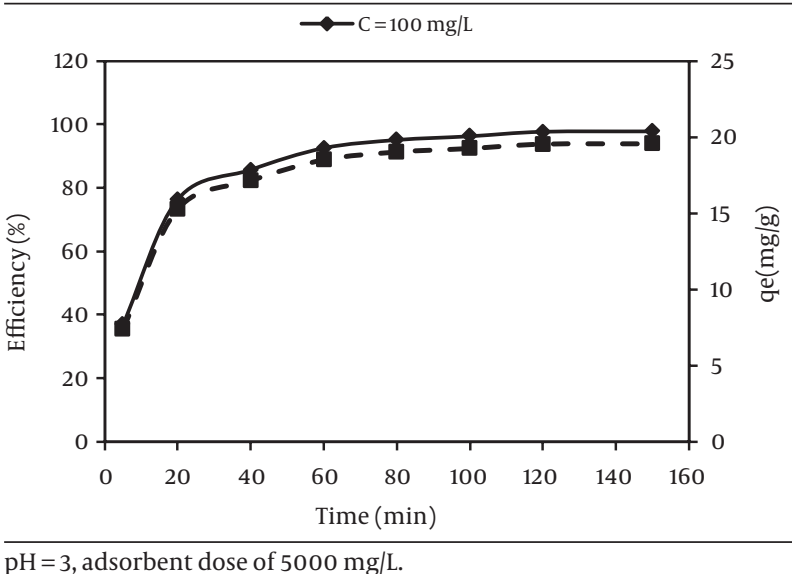

\subsection{The Effect of Adsorbent Dose and Initial Dye} Concentration

The effect of zero valent iron powder dosage on the dye removal percentage was investigated by adding various dosages of iron powder $(200-5000 \mathrm{mg} / \mathrm{L})$ to different dye concentrations $(20,50,100$ and $200 \mathrm{mg} / \mathrm{L})$ at contact time of 120 minutes and $\mathrm{pH}=3$. The effect of zero valent iron powder on dye adsorption is presented in Figure 3.

According to the results, by increasing the dose of iron powder from 200 to $5000 \mathrm{mg} / \mathrm{L}$ at dye concentration of $100 \mathrm{mg} / \mathrm{L}$, removal efficiency increased from $36.78 \%$ to $97.57 \%$, while adsorption capacity was reduced. In order for better understanding the effect of the iron powder dose on dye removal efficiency, a linear regression was drawn using MATLAB software version 7.8 (Figure 4) and the best qualification was related to the linear regression coefficient of R2 $>0.9278$. The effect of initial dye concentration is presented in Figure 5. By increasing dye concentration from 20 to $200 \mathrm{mg} / \mathrm{L}$ in the iron powder dose of $5000 \mathrm{mg} / \mathrm{L}$, the dye removal efficiency decreased from $99.41 \%$ to $96.85 \%$ although dye adsorption capacity increased from $3.97 \mathrm{mg} / \mathrm{g}$ to $38.78 \mathrm{mg} / \mathrm{g}$.

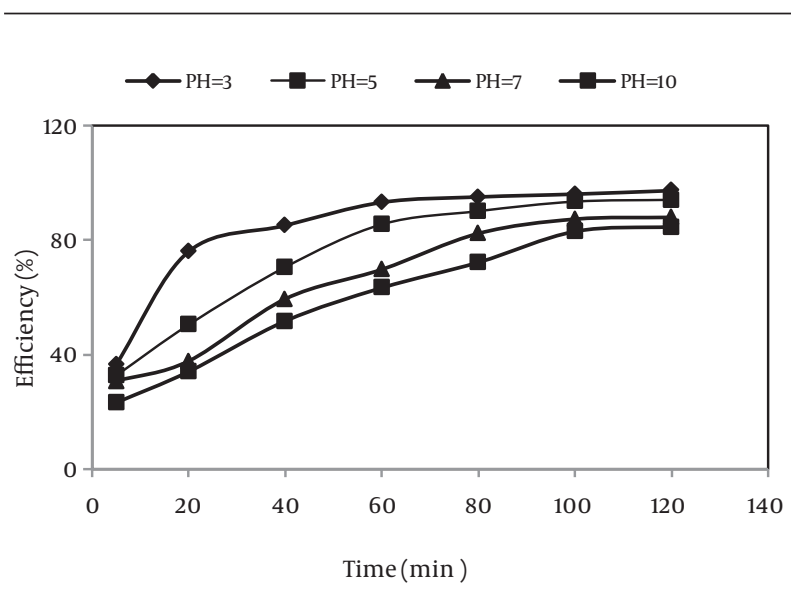

Figure 2. Effect of pH on RR-198 Adsorption Process Using $5000 \mathrm{mg} / \mathrm{L}$ of ZVI

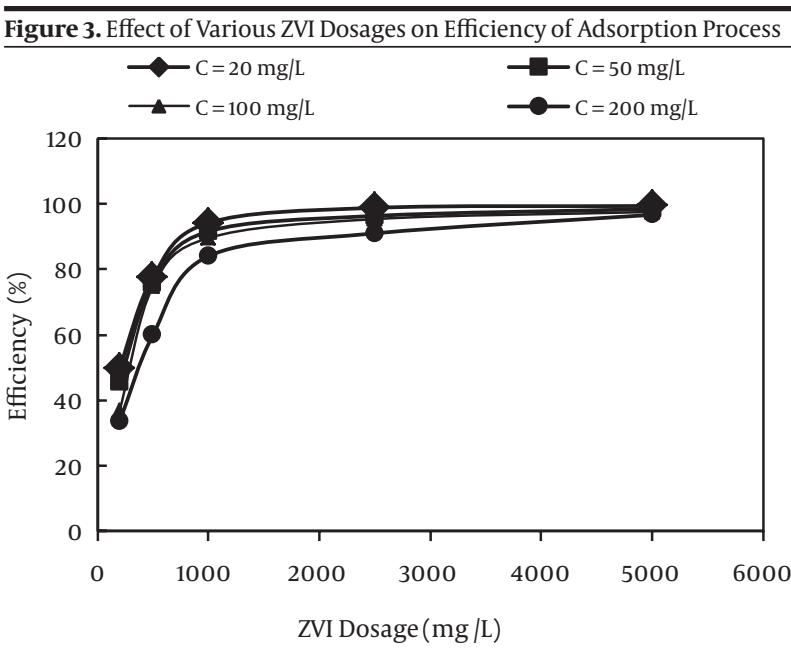

$\overline{\mathrm{pH}}=3$, contact time of 120 minutes and various dye concentrations

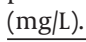

The decolorization efficiency of dyes reported in different articles has been summarized in Table 3. 
Figure 4. Multivariate Linear Regression Modeling of RR-198 Using ZVI Method

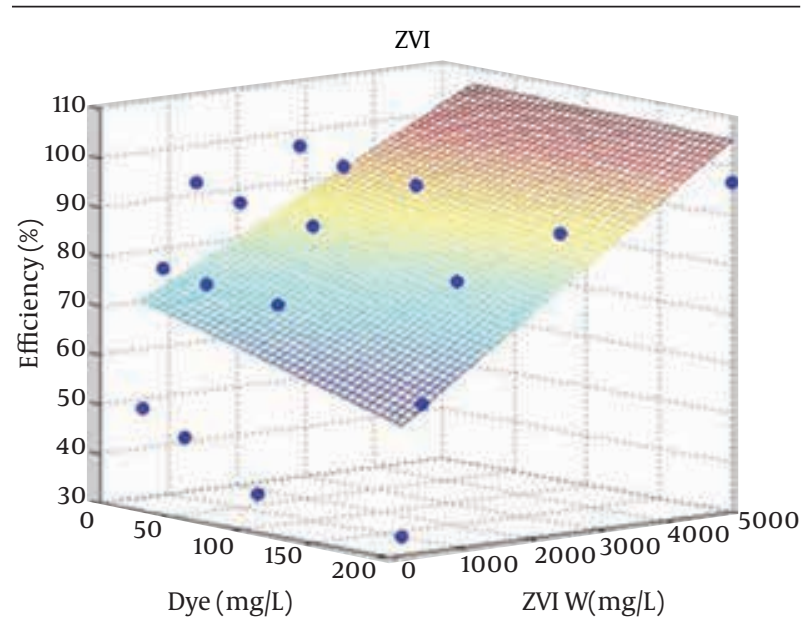

$\mathrm{pH}=3$, contact time of 120 minutes, various dye concentrations and various dosages of zero valent iron powder.
Figure 5. Effect of Initial Dye Concentration on Adsorption Efficiency

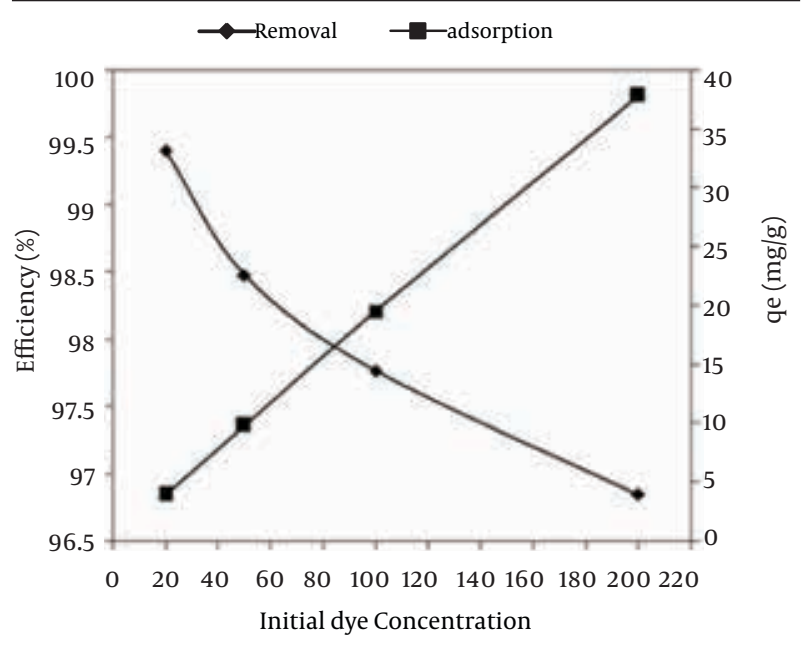

$\mathrm{pH}=3$, Contact Time of 120 Minutes.

Table 3. Decolorization of Azo Dyes by Different Methods (21-25)

\begin{tabular}{|c|c|c|c|c|}
\hline Dye & $\begin{array}{l}\text { Decolorization } \\
\text { methods }\end{array}$ & Conditions & $\begin{array}{l}\text { Decolorization } \\
\text { Efficiency, \% }\end{array}$ & References \\
\hline Reactive red 198 & $\begin{array}{l}\text { By Aspergillus parasiticus fungal } \\
\text { biosorbent }\end{array}$ & Time $=50 \mathrm{~min}$, temperature $50^{\circ} \mathrm{C}, \mathrm{pH}=2$ & 98.57 & $(21)$ \\
\hline Reactive red 198 & $\mathrm{UV} / \mathrm{TiO}_{2} / \mathrm{H}_{2} \mathrm{O}_{2}$ & Time $=35 \mathrm{~min},\left(\right.$ dye $50 \mathrm{mg} / \mathrm{L}, \mathrm{H}_{2} \mathrm{O}_{2}=450 \mathrm{mg} / \mathrm{L}$ & 100 & $(22)$ \\
\hline $\begin{array}{l}\text { Reactive red 198, } \\
\text { reactive black } 5\end{array}$ & nanoscale zerovalent iron & Time $=90 \mathrm{~min}, \mathrm{pH}=3$ & 70 & $(23)$ \\
\hline Reactive red 198 & ozonation & Time $=30 \mathrm{~min}$ & 96 & $(24)$ \\
\hline Reactive red 198 & $\begin{array}{c}\text { electrochemical coagulation } \\
\text { process }\end{array}$ & Time $=30 \mathrm{~min}$ & 99 & $(25)$ \\
\hline Reactive red 198 & zero valent iron & Time $=120 \mathrm{~min}, \mathrm{pH}=3$ & 97.57 & current study \\
\hline
\end{tabular}

Table 4. Results of Adsorption Isotherm Calculation

\begin{tabular}{|cc}
\hline Types of Isotherm & Temperature, $\mathbf{2 5}^{\circ} \mathbf{C}$ \\
\hline Freundlich & \\
\hline $\mathrm{N}$ & 1.524 \\
\hline $\mathrm{K}_{\mathrm{f}}$ & 3.491 \\
\hline $\mathrm{R}^{2}$ & 0.996 \\
\hline Langmuialpha & \\
\hline $\mathrm{Q}_{\mathrm{m}}$ & 32.258 \\
\hline $\mathrm{K}_{\mathrm{l}}$ & 0.111 \\
\hline $\mathrm{R}^{2}$ & 0.990 \\
\hline $\mathrm{K}_{\mathrm{T}}$ & 2.129 \\
\hline Temkin & \\
\hline $\mathrm{B}_{\mathrm{T}}$ & 8.738 \\
\hline $\mathrm{R}^{2}$ & 0.923 \\
\hline
\end{tabular}

\subsection{Adsorption Isotherm and Kinetics}

The results and parameters of the three isotherms and their correlation coefficients are shown in Table 4.

The study results indicated that in comparison to other isotherms, The Freundlich isotherm model had a better correlation in dye removal by ZVI $\left(\mathrm{R}^{2}=0.996\right.$ for $\left.25^{\circ} \mathrm{C}\right)$. Besides, by increasing the dye equilibrium concentration, the adsorption equilibrium capacity increased and maximum adsorption capacity of ZVI was obtained as 32.258 $\mathrm{mg} / \mathrm{g}$ at $25^{\circ} \mathrm{C}$. According to the results, the pseudo-second-order kinetic model was the most effective with $\mathrm{R}^{2}$ $=0.999$ for dye concentrations of 50,100 and $200 \mathrm{mg} / \mathrm{L}$. The results of the kinetics equations are shown in Table 5. The second-order rate constant $\mathrm{k}_{2}$ and $\mathrm{q}_{\mathrm{e}}$ are determined from the intercept and slope of the plot obtained by plotting $t / q_{t} v s$. T. Figure 6 shows the Freundlich adsorption isotherm and pseudo-second-order Kinetic model for RR198 dye adsorption by ZVI. 


\begin{tabular}{lcccc}
\hline Table 5. Results of the Kinetics Study & & & \\
\hline Kinetics & Parameters & \multicolumn{3}{l}{ Concentration, $\mathbf{~ m g / L}$} \\
\cline { 3 - 5 } & & $\mathbf{5 0}$ & $\mathbf{1 0 0}$ & $\mathbf{2 0 0}$ \\
\hline Pseudo-first-order & $\mathrm{k}_{1}$ & 0.036 & 0.036 & 0.034 \\
& $\mathrm{q}_{\mathrm{ecal}}$ & 4.591 & 11.402 & 24.888 \\
& $\mathrm{R}^{2}$ & 0.969 & 0.985 & 0.988 \\
\hline Pseudo-second-order & $\mathrm{k}_{2}$ & 0.017 & 0.005 & 0.002 \\
& $\mathrm{q}_{\mathrm{ecal}}$ & 10.416 & 21.276 & 43.478 \\
& $\mathrm{~h}$ & 1.848 & 2.506 & 3.984 \\
\hline Intra-particle & $\mathrm{R}^{2}$ & 0.999 & 0.999 & 0.999 \\
diffusion & $\mathrm{K}_{\mathrm{dif}}$ & 0.503 & 1.25 & 2.695 \\
& & & & \\
\hline & $\mathrm{C}$ & 5.035 & 7.536 & 12.48 \\
\hline
\end{tabular}
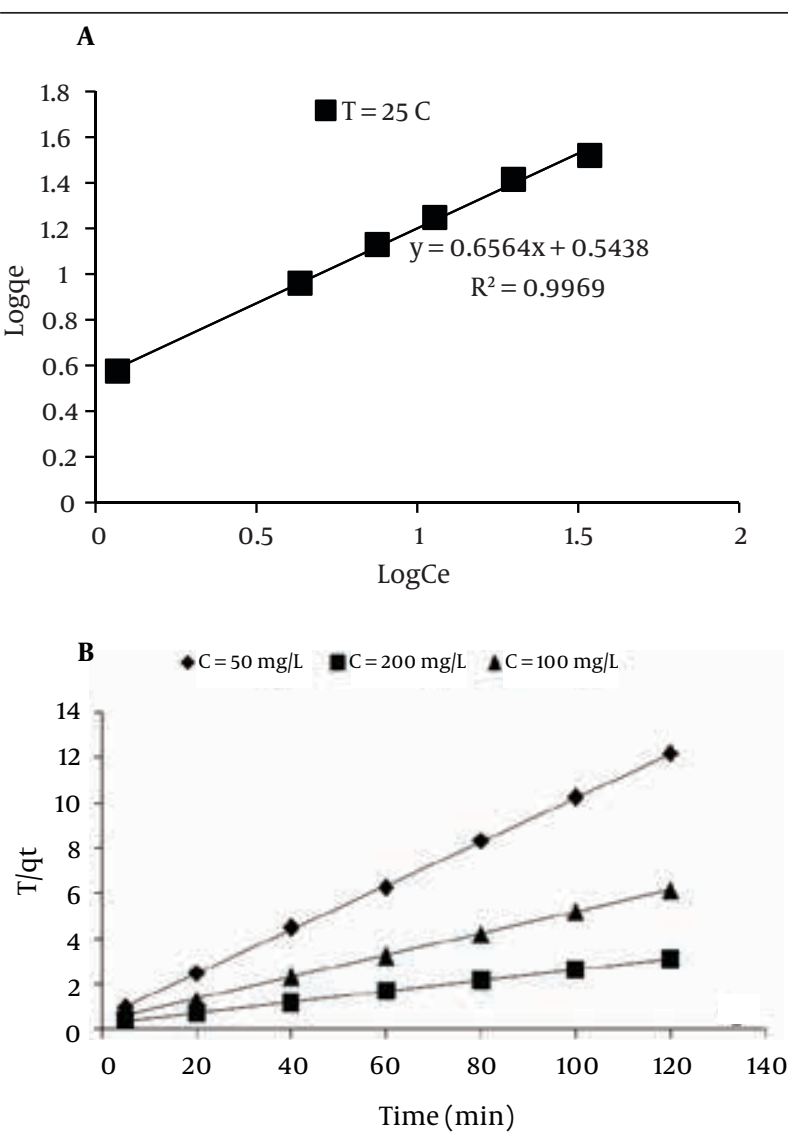

Figure 6. Modeling A) Freundlich Adsorption Isotherm and B) Pseudosecond-order Kinetic Model at different Dye Concentrations for RR-198 Adsorption Using ZVI

\section{Discussion}

\subsection{Contact Time}

According to the results, increasing the contact time in this system led to greater utilization of the iron powder active surface eventually resulting in production of more free electrons, owing to higher quantities of $\mathrm{Fe}^{2+}$ ions in solution in acidic conditions. Therefore, the oxidation rate of RR-198 in the ZVI reaction is higher (26). The results of the study by Chang et al. (15) showed that at $2 \mathrm{~g} / \mathrm{L}$ dose of zero valent iron, dye removal percentage reached its maximum range in the first 15 minutes, while no change was observed in dye removal after 120 minutes. The results of the study conducted by Rahmani et al. (2) on removing the two reactive dyes - reactive black 5 and acid orange 7 - using the Fenton-like mechanism showed that in $\mathrm{Fe}^{0}$ and $\mathrm{Fe}^{\mathrm{O}} / \mathrm{UV}$ systems the maximum dye removal was obtained at $\mathrm{pH}=3$ and an equilibrium time of 120 minutes.

\section{2. $p H$}

Considering the fact that dye removal efficiency is maximized in acidic solutions, $\mathrm{pH}=3$ was used as the optimum $\mathrm{pH}$ level in further experiments. In general, more $\mathrm{H}^{+}$exists in acidic solutions compared to basic solutions and consequently the reaction between the dye and the zero valent iron is stronger at basic $\mathrm{pH}$ levels. On the other hand, due to existing hydroxyl ions, $\mathrm{Fe}^{3+}$ is converted to $\mathrm{F}_{\mathrm{e}}(\mathrm{OH})_{3}$. This is mainly because of the hydrolyzation of iron ions and deposition of iron oxide on the metallic iron surface, which leads to occupation of active sites, slows the reaction speed, and eventually stops the reaction $(27,28)$. In the study by Satapanajaru et al. (29) on removing reactive red 198 and reactive black 5 dyes using iron nanoparticles, reduction of $\mathrm{pH}$ from 9 to 3 increased the kinetic speed of dye removal reaction. For both dyes, the removal efficiency reached $100 \%$ after 120 minutes. In the study conducted by Gomathi et al. (30) on methyl orange dye removal using the advanced Fenton process zero valent metallic iron, it was found that by decreasing $\mathrm{pH}$ from 9 to 2 , the efficiency of dye removal increased, and optimal standard condition was found to be in $\mathrm{pH}=3$.

\subsection{Adsorbent Dose and Initial Dye Concentration}

In the zero valent iron powder system, increasing the iron powder dose raises the level of raw materials producing free electrons. Therefore, the free electrons production escalates leading to higher efficiency. Also, by increasing the iron dosage, more active sites are created for more rapid reaction speed at the initial stages and, as a result, more iron particles contact with dye molecules eventually increasing the dye removal efficiency $(29,31)$. As a result, increasing iron powder has a greater effect on dye removal. Deng et al. (32) also conducted a study on reactive dye removal utilizing the $\mathrm{UV} / \mathrm{Fe}^{0}$ process and showed that by increasing the iron dose from 0.5 to $4 \mathrm{~g} / \mathrm{L}$ in acidic $\mathrm{pH}$, the dye removal speed improved. Daud et al. (33) studied acidic dye removal with the Fenton-like process, by increasing the catalyst dose from 2 to $5 \mathrm{~g} / \mathrm{L}$ with a contact time of 150 minutes, where the removal rate of acid red 1 reached 99\%. The findings of the current study showed that as the dye concentration increased, the re- 
moval efficiency was decreased. This might be due to the saturation of the adsorption sites by the adsorbent in lower dye concentrations (34). In the study by Chang et al. (35) on dye removal through $\mathrm{Fe}^{0}$ air process with reactive black 4 and 5, the removal percentage decreased in higher dye concentrations where the highest removal percentage was related to the concentration of $50 \mathrm{mg} / \mathrm{L}$ with 99\% removal efficiency. The results of the study conducted by He et al. (31) on removing the Reactive dyes using zero-valent iron showed that by increasing the initial dye concentration from $300 \mathrm{mg} / \mathrm{L}$ to $700 \mathrm{mg} / \mathrm{L}$, the decolorization efficiency decreased from $98.53 \%$ to $97.89 \%$ for reactive brilliant red $\mathrm{K}-2 \mathrm{G}$, and from $99.8 \%$ to $95.74 \%$ for reactive brilliant blue $\mathrm{KN}-\mathrm{R}$ and from $99.64 \%$ to $99.22 \%$ for malachite green.

\subsection{Adsorption Isotherm and Kinetics}

As shown in Table 4, the Freundlich isotherm model had better correlation compared to other isotherms. By increasing the dye equilibrium concentration, the adsorption equilibrium capacity is increased. This is due to the accessibility of the adsorption sites at the initial moments of the process. In general, values of $\mathrm{n}$ in ranges of 1 to 10 illustrated that the adsorbate was favorably adsorbed by the adsorbent (36). The value of $n 1.524$, at $25^{\circ} \mathrm{C}$ was greater than 1, indicating favorable removal conditions. Qadri et al. (37) conducted a study on cridine Orange using magnetic Nanoparticles. The results showed that Freundlich isotherm and pseudo-second-order kinetic model were the best for describing the reaction of adsorption. Iram et al. (38) conducted a study on neutral red dye removal using $\mathrm{Fe}_{3} \mathrm{O}_{4}$ hollow nanospheres, and found that pseudo-second-order kinetic model was the dominant model for dye concentrations of 20, 50, 100, 150 and $200 \mathrm{mg} / \mathrm{L}$ with $\mathrm{R}^{2}>0.999$ (Table 6).

Iron powder is easy to use and can be continuously utilized due to its recyclability. Therefore, it is highly economical in removing azo dyes. Acidic $\mathrm{pH}$ is one of the effective factors in increasing the efficiency of zero valent iron powder and at $\mathrm{pH}=3$, the dye removal efficiency reaches its maximum level. Moreover, maximum adsorption was

Table 6. Notations Used in Kinetic Models

\begin{tabular}{lc}
\hline & Nomenclature \\
\hline $\begin{array}{l}\text { Pseudo first-order rate constant, 1 min } \\
\begin{array}{l}\text { Pseudo second-order rate constant, } \mathbf{g} / \mathbf{m g} \\
\text { min }\end{array}\end{array}$ & $\mathrm{K}_{1}$ \\
$\begin{array}{l}\text { Intraparticle diffusion rate constant, } \\
\text { mg/g min } 0.5\end{array}$ & $\mathrm{~K}_{\mathrm{dif}}$ \\
$\begin{array}{l}\text { Equilibrium adsorbent concentration on } \\
\text { adsorbent, mg/g }\end{array}$ & $\mathrm{q}_{\mathrm{e}}$ \\
$\begin{array}{l}\text { Calculated values of } \mathbf{q}_{\mathrm{e}}, \mathbf{m g} / \mathbf{g} \\
\text { Maximum monolayer capacity, } \mathbf{m g} / \mathbf{g}\end{array}$ & $\mathrm{q}_{\mathrm{ecal}}$ \\
Correlation coefficients & $\mathrm{Q}_{\mathrm{m}}$ \\
\hline
\end{tabular}

observed at $5000 \mathrm{mg} / \mathrm{L}$ dose of zero valent iron powder and contact time of 120 minutes. Freundlich isotherm and pseudo-second-order Kinetic model are the best for describing the RR-198 adsorption reaction on zero valent iron powder catalyst. However, acidification of the environment is one of the major limitations of this method.

\section{Acknowledgements}

The authors would like to express their thanks to the personnel of the Health School of Shiraz University of Medical Sciences.

\section{Authors' Contribution}

The overall implementation of this study including design, experiments, data analysis and manuscript preparation were the results of joint efforts by individuals who are listed as coauthors of this paper. All authors made extensive contributions to the review and finalization of this manuscript.

\section{Financial Disclosure}

The authors declare that there were no conflicts of interests.

\section{Funding/Support}

This article was extracted from Soudabeh Pourfadakar's MSc thesis approved by Shiraz University of Medical Sciences, Shiraz, Iran (grant No. 91/6133).

\section{References}

1. Shih YH, Tso CP, Tung LY. Rapid degradation of methyl orange with nanoscale zerovalent iron particles. J Environ Eng Manage. 2010;20(3):137-43.

2. Rahmani AR, Zarrabi M, Samarghandi MR, Afkhami A, Ghaffari HR. Degradation of azo dye reactive black 5 and acid orange 7 by fenton-like mechanism. Iran J Chem Eng. 2010;7(1):87-94.

3. Mahvi AH, Heibati B. Removal efficiency of azo dyes from textile effluent using activated carbon made from walnut wood and determination of isotherms of acid red 18. J Health Hygiene Ardebill. 2011;1(3):5-17.

4. Carpenter J, Sharma S, Sharma AK, Verma S. Adsorption of dye by using the solid waste from leather industry as an adsorbent. Adsorption. 2013;2(1).

5. Tan LS, Jain K, Rozaini CA. Adsorption of textile dye from aqueous solution on pretreated mangrove bark, an agricultural waste: equilibrium and kinetic studies. J Appl Sci Environ Sanitation. 2010;5(3):283-94.

6. Mahvi AH, Ghanbarian M, Nasseri S, Khairi A. Mineralization and discoloration of textile wastewater by TiO2 nanoparticles. Desalination. 2009;239(1-3):309-16.

7. Handan U. Equilibrium, thermodynamic and kinetics of reactive black 5 biosorption on loquat (Eriobotrya japonica) seed. Sci Res Essays. 2011;6(19):4113-24.

8. Hashemian S. Removal of Methyl Violet by Adsorption onto Bentonite with Copper Ferrite Nano-Particles. J Color Sci Technol. 2011;4:191-7.

9. Chompuchan C, Satapanajaru T, Suntornchot P, Pengthamkeerati P. Decolorization of reactive black 5 and reactive red 198 using nanoscale zerovalent iron. World Acad Sci Eng Technol. 2009;25:104-8. 
10. Gholami-Borujeni F, Mahvi AH, Nasseri S, Faramarzi MA, Nabizadeh R, Alimohammadi M. Enzymatic treatment and detoxification of acid orange 7 from textile wastewater. Appl Biochem Biotechnol. 2011;165(5-6):1274-84

11. Gholami-Borujeni F, Mahvi AH, Naseri S, Faramarzi MA, Nabizadeh R, Alimohammadi M. Application of immobilized horseradish peroxidase for removal and detoxification of azo dye from aqueous solution. Res J Chem Environ. 2011;2:217-22.

12. Poursaberi T, Hassanisadi M, Nourmohammadian F. Application of synthesized nanoscale zero-valent iron in the treatment of dye solution containing basic yellow 28. Prog Colo Colorants Coatings. 2012;5:35-40.

13. Zarrabi M, Samarghndi MR, Rahmani AR, Noori Sepehr ME, Mohamadi Kalhori SJ, Jafari S. [Kinetic study of acid red 18 and acid red 14 removal from aqueous solution using metallic iron]. Iran J Health Hygiene Ardebil. 2011;3(31):31-40.

14. $\mathrm{Wu} \mathrm{CH}$. Adsorption of reactive dye onto carbon nanotubes: equilibrium, kinetics and thermodynamics. J Hazard Mater 2007;144(1):93-100.

15. Chang MC, Shu HY, Yu HH, Sung YC. Reductive decolourization and total organic carbon reduction of the diazo dye $\mathrm{Cl}$ Acid Black 24 by zero-valent iron powder. J ChemTech Biotechnol. 2006;81(7):1259-66.

16. Clesceri LS, Eaton AD, Greenberg AE, American Public Health As sociation , American Water Works Association , Water Environment Federation. Standard Methods for the Examination of Water and Wastewater: American Public Health Association; 1998.

17. Dhafir T, Al-heetimi A, Dawood AH, Khalaf QZ, Himdan TA. [Removal of methyl orange from aqueous solution by iraqi bentonite adsorbent]. J Pure and Appl Sci. 2012;25(1):1-13.

18. Thinakaran N, Baskaralingam P, Pulikesi M, Panneerselvam P, Sivanesan S. Removal of Acid Violet 17 from aqueous solutions by adsorption onto activated carbon prepared from sunflower seed hull. J Hazard Mater. 2008;151(2-3):316-22.

19. Temkin M, Pyzhev J. Kinetics of ammonia synthesis on promoted Iron catalysts. Acta Physio Physiochem. 1940;2:217-29.

20. Amin NK. Removal of direct blue-106 dye from aqueous solution using new activated carbons developed from pomegranate peel adsorption equilibrium and kinetics. J Hazard Mater. 2009;165(1 3):52-62.

21. Akar ST, Akar T, Çabuk A. Decolorization of a textile dye, reactive red 198 (rr198), by Aspergillus parasiticus fungal biosorbent. Brazilian J Chem Eng. 2009;26:399-405.

22. Mahmoodi NM, Arami M, Limaee NY. Photocatalytic degradation of triazinic ring-containing azo dye (Reactive Red 198) by using immobilized TiO2 photoreactor: Bench scale study. J Hazad Mater. 2006;133(1-3):113-8.

23. Satapanajaru T, Chompuchan C, Suntornchot P, Pengthamkeerati P. Enhancing decolorization of Reactive Black 5 and Reactive Red 198 during nano zerovalent iron treatment. Desalination. 2011;266(1):218-30.
24. Ghaneian MT, Ehrampoush MH, Ganizadeh G, Askar Shahi M Momtaz M. [Application of Ozonation on the removal of reactive red 198 dye at alkaline condition]. J Toloo-e-Behdasht. 2010:11-21.

25. Dalvand A, Gholami M, Joneidi A, Mahmoodi NM. Investigation of electrochemical coagulation process efficiency for removal of Reactive Red 198 from colored wastewater. J Color Sci Tech. 2009;3:97-105.

26. Barbusiński K, Majewski J. Discoloration of azo dye Acid Red 18 by Fenton reagent in the presence of iron powder. Polish J Environ Stud. 2003;12(2):151-5.

27. Pereira WS, Freire RS. Azo dye degradation by recycled waste zero-valent iron powder.J Brazilian Chem Soc. 2006;17:832-8.

28. Cao J, Wei L, Huang Q, Wang L, Han S. Reducing degradation of azo dye by zero-valent iron in aqueous solution. Chemosphere. 1999;38(3):565-71.

29. Satapanajaru T, Chompuchan C, Suntornchot P, Pengthamkeerati P. Enhancing decolorization of Reactive Black 5 and Reactive Red 198 during nano zerovalent iron treatment. Desalination. 2011;266(1-3):218-30.

30. Gomathi Devi L, Girish Kumar S, Mohan Reddy K, Munikrishnappa C. Photo degradation of Methyl Orange an azo dye by Advanced Fenton Process using zero valent metallic iron: Influence of various reaction parameters and its degradation mechanism. J Hazard Mater. 2009;164(2-3):459-67.

31. He Y, Gao JF, Feng FQ, Liu C, Peng YZ, Wang SY. The comparative study on the rapid decolorization of azo, anthraquinone and triphenylmethane dyes by zero-valent iron. Chem Eng J. 2012;179:818.

32. Deng N, Luo F, Wu F, Xiao M, Wu X. Discoloration of aqueous reactive dye solutions in the UV/Feo system. Water Res 2000;34(8):2408-11.

33. Daud NK, Ahmad MA, Hameed BH. Decolorization of Acid Red 1 dye solution by Fenton-like process using Fe-Montmorillonite K10 catalyst. Chem EngJ. 2010;165(1):111-6.

34. Khorramfar S, Mahmoodi NM, Arami M, Gharanjig K. Dye removal from colored textile wastewater using tamarindus indica hull: Adsorption isotherm and kinetics study. J Color Sci Tech. 2009;3:81-8.

35. Chang SH, Wang KS, Chao SJ, Peng TH, Huang LC. Degradation of azo and anthraquinone dyes by a low-cost Fe 0/air process. J Hazard Mater. 2009;166(2-3):1127-33.

36. Konicki W, Pełech I, Mijowska E, Jasińska I. Adsorption of anionic dye Direct Red 23 onto magnetic multi-walled carbon nanotubes-Fe3C nanocomposite: Kinetics, equilibrium and thermodynamics. Chem Eng J. 2012;210:87-95.

37. Qadri S, Ganoe A, Haik Y. Removal and recovery of acridine orange from solutions by use of magnetic nanoparticles. J Hazard Mater. 2009;169(1-3):318-23.

38. Iram M, Guo C, Guan Y, Ishfaq A, Liu H. Adsorption and magnetic removal of neutral red dye from aqueous solution using $\mathrm{Fe} 3 \mathrm{O} 4$ hollow nanospheres. J Hazard Mater. 2010;181(1-3):1039-50. 